\title{
MENINGKATKAN KARAKTER PEDULI LINGKUNGAN MELALUI KEGIATAN BERKEBUN KELOMPOK B DI RA PERWANIDA 4 JAKABARING PALEMBANG
}

\author{
Annisa Dwi Marietta1, Dr. Evia Darmawani, M.Pd. Kons², \\ Romadona Noverina, S.Pd., M.Si ${ }^{3}$
Email : annisadm1998@gmail.com ${ }^{1}$,evia.syamsuddin@gmail.com², romadonanoverina71@gmail.com ${ }^{3}$

\begin{abstract}
Abstrak: Penelitian ini bertujuan untuk meningkatan karakter peduli lingkungan melalui kegiatan berkebun pada anak kelompok B RA Perwanida 4 Jakabaring Palembang. Jenis penelitian ini adalah Penelitian Tindakan Kelas (PTK) dengan metode pengumpulan data observasi dan dokumentasi. Waktu pelaksanaan penelitian ini adalah bulan Juli-Agustus 2019. Yang diteliti dalam penelitian ini adalah anak kelompok B3 berjumlah 17 Orang. Teknik analisis data dilakukan dengan menggunakan data deskriptif dengan analisis refleksi. Penelitian ini menunjukkan bahwa karakter anak peduli terhadap lingkungan di RA Perwanida 4 Jakabaring Palembang dilakukan melalui kegiatan berkebun, aspek penilaian yang dapat dilihat yaitu kepedulian, sikap, dan tindakan (perbuatan). Dalam ketiga aspek tersebut dilakukan 2 siklus, Siklus I terdiri dari 4 kali pertemuan, dan Siklus II terdiri dari 4 kali pertemuan. Sebelum memasuki siklus I ada tahap pra tindakan. Pra tindakan dilakukan untuk tahap awal, siklus I tahap permulaan, dan siklus II tahap perubahan. Hasil penelitian ini menunjukkan dari tahap pra tindakan, Siklus I ke Siklus II selalu mengalami peningkatan. Kegiatan berkebun merupakan dimana anak dapat melakukan kegiatan secara langsung dengan tanaman dan tumbuhan di lingkungan sekolah, melalui kegiatan berkebun, dengan dilakukan kegiatan menanam sayur bayam pada siklus I, dan menanam sayur katu pada siklus II. Dapat dilihat dari hasil penelitian bahwa dari tahap pra tindakan yang memiliki ketuntasan $0 \%$, siklus I mengalami kenaikan 17\%, dan siklus II mengalami kenaikan 77\%, nilai ketuntasan ini dilihat dari pertemuan 1-4.
\end{abstract}

Kata kunci: Karakter, Peduli Lingkungan Dan Kegiatan Berkebun.

\section{PENDAHULUAN}

Pendidikan anak usia dini merupakan suatu pendidikan awal untuk mencapai atau meraih masa keemasan (golden age) / dimana pada masa ini anak mulai peka terhadap lingkungan, hal ini bisa dibilang sebagai suatu upaya pembinaan yang ditujukan bagi anak sejak lahir sampai usia enam tahun. Kegiatan ini dapat dilakukan melalui pemberian rangsangan atau stimulus dalam rangka membantu pertumbuhan dan perkembangan jasmani dan rohaninya.

Di samping itu, pendidikan anak usia dini lebih mengedepankan dan dianjurkan belajar seraya bermain, dimana dalam usia ini anak tidak boleh dituntut harus bisa melainkan paling tidak tahap pengenalan terlebih dahulu, sehingga pada usia selanjutnya anak tidak akan merasakan titik jenuh atau kebosanan dalam belajar. Dalam penyelenggaraan PAUD tersebut, salah satu tujuan umum adalah "Pembentukan Karakter".

$$
\text { Pendidikan karakter yang }
$$
orientasinya untuk membekali pengetahuan, pemahaman, penghayatan dan pengalaman nilai-nilai keutamaan dalam hidup (living values) kepada peserta didik juga mendesak dilakukan. Nilai-nilai 
tersebut meliputi kasih sayang dan empati, kerjasama, keberanian, tolong menolong, kesabaran, tanggung jawab, tenggang rasa, harga diri, dan kemandirian.

Salah satu upaya menanamkan karakter pada Anak Usia Dini, melalui peduli lingkungan bagi anak, melalui kegiatan pembelajaran berkebun. Berkebun merupakan suatu kegiatan yang dilakukan di alam terbuka atau di luar kelas caranya dengan mengajak anak, antara lain bercocok tanam, mengenal tumbuh-tumbuhan, dan cara merawat tanaman dengan baik. Di samping itu melalui berkebun ada nilai edukatifnya, seperti anak akan mengerti arti menghargai makhluk hidup dan lainnya. Tumbuhtumbuhan yang harus dijaga begitu juga dengan kelestarian lingkungannya dan membantu anak-anak dalam mengkoordinasikan kemampuan gerak melalui aktivitas di alam bebas.

Berdasarkan hasil pembelajaran selama ini baik yang dilakukan dewan guru dan bekerja sama dengan orang tua anak didik di kelas maupun diluar kelas B RA Perwanida 4 Jakabaring Palembang, perilaku anak didik yang menunjukkan karakter peduli lingkungan masih belum berkembang sesuai yang diharapkan, diantaranya; rentan sekali merasa takut dan ragu, jijik memegang sesuatu yang ada di kebun. Pada saat ia bertemu dengan benda asing dia akan berteriak, berlari, meloncatloncat ketakutan dan meninggalkan tempat tersebut. Banyak terdapat di lingkungan sekolah itu memiliki tanaman yang berawa, didalam tanaman itu terkadang ada ulat yang menjadi faktor utama anak merasa takut, serta ulat itu kadang hinggap di tangannya.

Hal ini ditunjukkan dari 17 anak, belum ada anak yang telah mampu menunjukkan karakter peduli lingkungan melalui kegiatan berkebun. Karakter anak terlihat pada saat kegiatan itu, ada beberapa anak yang antusias pada saat diajak ke kebun dengan aktivitas menanam berbagai tumbuh-tumbuhan, ada juga anak yang merasa takut, bosan, histeris, serta marah ketika melihat hal yang dianggap aneh baginya. Ketika menemukan anak yang antusias pada saat kegiatan berkebun, ia akan menampakkan mimik muka bahagia, dan anak yang tidak mempunyai rasa antusias pada saat kegiatan berkebun itu, ia akan sedih, cemberut, diam dan marah. Hasil wawancara dengan tenaga pendidik di RA Perwanida 4 Jakabaring Palembang, terdapat guru yang mengatakan bahwa ada beberapa anak yang antusias pada saat kegiatan pembelajaran berkebun tetapi untuk mempraktekkan dan melatih anak merawat tanaman dan lingkungan melalui kegiatan berkebun itu sendiri belum meningkat 
dengan baik maka dari itu tergantung penanaman dari karakter peduli lingkungan anak didik itu sendiri.

Berdasarkan latar belakang, maka rumusan masalah dalam penelitian adalah "Bagaimana cara meningkatkan karakter peduli lingkungan melalui kegiatan berkebun pada anak kelompok B di RA Perwanida 4 Jakabaring Palembang.

Penelitian ini bertujuan untuk mengetahui cara meningkatkan karakter peduli lingkungan melalui kegiatan berkebun pada anak kelompok B di RA Perwanida 4 Jakabaring Palembang.

\section{KAJIAN TEORITIK}

\section{A. Peduli Lingkungan Pada Anak Usia Dini}

Kemendikbud (2013) menjelaskan peduli lingkungan adalah "nilai yang didasarkan pada sikap dan perilaku yang penuh perhatian dan rasa sayang terhadap keadaan yang ada di lingkungan sekitarnya dengan cara memperhatikan, mengamati, dan mencintai lingkungan”.

Menurut Hadi Nur (2014: 477) menyatakan sebagai berikut bahwa: Kepedulian lingkungan adalah suatu cara manusia dalam melestarikan lingkungan agar tidak terganggu/diganggu oleh manusia lain yang tidak bertanggung jawab.
Setiyani (2013) menyebutkan peduli lingkungan berarti "mengindahkan atau menghiraukan lingkungan yang ada di lingkungan sekitarnya. Kegiatan tersebut seperti berkebun, bercocok tanam, melestarikan lingkungan alam bebas dan lain sebagainya".

Berdasarkan pendapat para ahli di atas dapat disimpulkan, karakter peduli lingkungan adalah nilai yang berupa sikap dan perilaku seseorang dalam berupaya mencegah kerusakan pada lingkungan alam sekitar kita dan mencegah kerusakan lingkungan itu terjadi.

\section{B. Cara Pembelajaran Berkebun di PAUD}

Menurut Musfiroh (2010: 8.32) menyatakan sebagai berikut:

Kegiatan ini dapat dilakukan di TPA, KB, dan TK dengan cara-cara berikut:

1) Siapkan beberapa kotak media tanam ukuran sedang hingga besar yang satu sisinya berupa kaca.

2) Masukkan tanah gembur sebagai media tanam kira-kira $10 \mathrm{~cm}$, beri air secukupnya.

3) Masukkan biji jagung, biji kacang panjang, biji kedelai, biji kacang hijau, pada media 1, biji cabe, biji tomat, semangka, kecipir, dan padi pada media 2, dan biji rambutan, biji 
mangga, biji jambu air, biji durian, dan biji salak pada media 3 .

4) Ajak anak-anak mengamati seksama setiap perubahan yang terjadi pada biji dan tunas dari hari ke hari.

5) Teruslah mengamati, menyirami, bertanya jawab dengan anak, dan pindahkan ke media lain untuk tanaman besar, seperti tunas mangga, rambutan, durian, dan salak.

6) Jika Proyek berhasil, lakukan proyek dengan tanaman lain pada semester berikutnya.

Menurut Asmawati (2014: 4.29) menjelaskan beberapa peralatan berkebun yang disarankan:

1) beberapa perlengkapan untuk berkebun.

2) gerobak tangan.

3) benih atau biji-bijian.

4) kantong kotor dan bersih.

5) fasilitas air.

6) tempat menyiram bunga.

7) tali dan kayu untuk memberi tanda jalan.

Berdasarkan beberapa pendapat di atas dapat disimpulkan cara pembelajaran berkebun itu, jika ingin memilih perlengkapan berkebun yang dibutuhkan dapat disesuaikan dari ketersediaan alat disekolah yang bersifat aman bagi anak usia dini.

\section{METODOLOGI PENELITIAN}

Penelitian yang dilakukan oleh peneliti adalah penelitian tindakan kelas karena penelitian ini ingin memperbaiki pembelajaran anak untuk implementasi pada teori yang dikumpulkan, hal ini berpedoman dengan;

Menurut Wardhani (2013:1.4) mengatakan : Penelitian Tindakan Kelas (PTK) adalah "Penelitian yang dilakukan oleh guru di dalam kelasnya sendiri melalui refleksi diri, dengan tujuan untuk memperbaiki kinerjanya sebagai guru, sehingga hasil belajar siswa menjadi meningkat".

Mertler (2014: 4) menjelaskan sebagai berikut: Penelitian tindakan didefinisikan sebagai penyelidikan sistematis yang dilakukan oleh para guru, administrator, konselor, atau orang lain dengan satu kepentingan tertentu dalam proses mengajar dan belajar atau lingkungan dengan tujuan mengumpulkan informasi tentang bagaimana sekolah mereka belajar.

Zainal (2017: 13) menjelaskan sebagai berikut: PTK merupakan Penelitian yang dilakukan oleh guru di kelas (sekolah) tempat ia mengajar dengan tekanan pola penyempurnaan atau peningkatan proses dan praktis pembelajaran. Model penelitian yang digunakan ialah Model Kemmis dan 
Taggart dengan 2 siklus, setiap siklus dilakukan empat kali pertemuan dan dalam satu siklus terdiri dari empat komponen yaitu: Perencanaan, Tindakan, Observasi dan Refleksi.

Berdasarkan pendapat para ahli diatas dapat disimpulkan, Penelitian tindakan kelas (PTK) adalah penelitian yang dilakukan guru yang sudah memegang kelas sendiri untuk mengetahui ada/tidak adanya peningkatan proses pembelajaran anak didik pada saat pembelajaran berlangsung.

Model dan desain yang digunakan dalam penelitian tindakan kelas ini adalah model Kemmis \& Mc Taggart, yang terdiri dari empat komponen dalam satu siklus yakni: perencanaan, tindakan, observasi, dan refleksi.

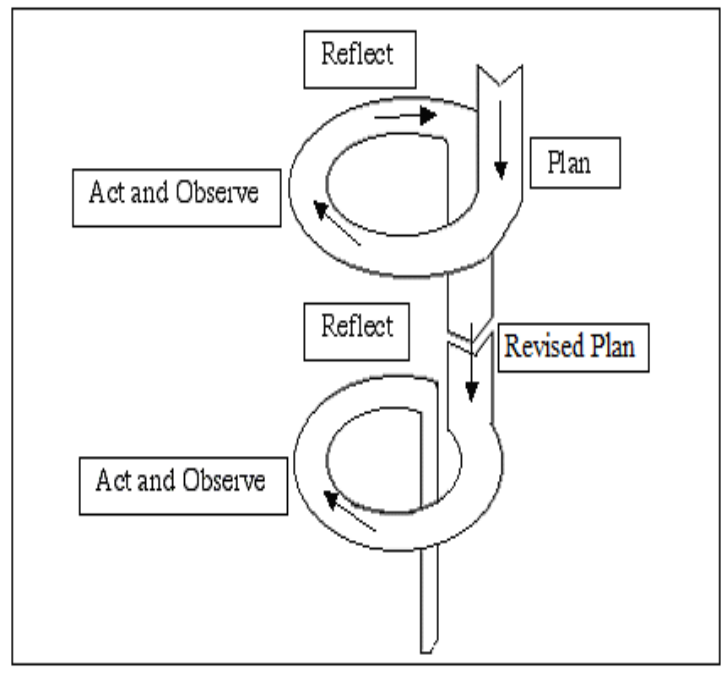

Tabel 3.1. Model Spiral Kemmis \& Mc Taggart

Prosedur penelitian yang dilakukan dalam Penelitian Tindakan Kelas (PTK) ini adalah bentuk Kemmis dan Mc Taggart (2012) yang terdiri dari beberapa siklus dan masing-masing siklus terdiri dari beberapa tindakan. Siklus dihentikan apabila melalui kegiatan berkebun yang dilakukan telah berhasil meningkatkan

\section{1) Observasi}

Menurut Wina Sanjaya (2009: 86) mengemukakan bahwa, observasi merupakan teknik mengumpulkan data dengan cara mengamati setiap kejadian karakter peduli lingkungan anak RA Perwanida 4 Jakabaring Palembang.

Teknik pengumpulan data dalam menanamkan karakter peduli lingkungan melalui kegiatan berkebun menggunakan teknik sebagai berikut: Observasi, wawancara, dan dokumentasi.

yang sedang berlangsung dan mencatatnya dengan alat observasi tentang hal-hal yang akan diamati atau diteliti. Anak menunjukkan sikap antusias dalam kegiatan dengan mimik 
muka, senang, gembira, percaya diri, serta mampu bekerjasama. Ada pula anak yang menunjukkan sikap tidak antusias dalam kegiatan ini dengan mimik muka takut, sedih, serta diam.

\section{2) Dokumentasi}

Menurut Wahyudin dan Agustin (2011: 61) dokumentasi adalah pengambilan data yang diperoleh melalui dokumen-dokumen. Penelitian ini dokumentasi digunakan untuk memperoleh data anak sebelum dan sesudah melakukan pembelajaran. Dokumentasi dapat berupa berbentuk tulisan atau gambar, video, dan lainlain.

Keterangan:

$\mathrm{P}=$ Angka prestasi

$\mathrm{F}=$ Frekuensi nilai siswa

$\mathrm{N}=$ Jumlah anak dalam 1 kelas

$$
\mathrm{P}=\underline{\mathrm{F}} \times 100 \%
$$

\section{HASIL DAN PEMBAHASAN}

\section{A. Hasil}

Penelitian yang telah dilakukan adalah jenis Penelitian Tindakan Kelas (PTK). Penelitian ini terdiri dari dua siklus, siklus I dan siklus II masing-masing terdiri dari perencanaan, tindakan dan observasi, serta refleksi. Sebelum
Analisis data yang digunakan dalam penelitian tindakan kelas ini adalah data deskriptif dengan analisis refleksi. Analisis deskriptif untuk memberikan deskripsi mengenai objek penelitian berdasarkan hasil data observasi yang diperoleh peneliti dengaan kriteria keberhasilan yang telah di tetapkan. Hal ini dilakukan dengan cara membandingkan frekuensi munculnya indikator sikap peduli lingkungan pada anak sebelum dan sesudah dilakukan tindakan pemberian pembelajaran kegiatan berkebun.

Sasaran tindakan persentase perubahan sikap peduli lingkungan dihitung dengan menggunakan rumus sebagai berikut:

memasuki siklus I dan II, ada tahap pra tindakan. Dimana masa pra tindakan ini sudah dapat melihat tingkat kecapaian anak, tetapi masa ini dilakukan satu kali saja pada saat observasi. Setelah itu kita masuk ke siklus I. Siklus I adalah suatu penelitian yang dilihat dari tahap awal sebelum memasuki siklus II. Siklus II 
adalah perubahan dari siklus I secara keseluruhan karakter peduli lingkungan anak mengalami peningkatan. Pada pelaksanaan siklus I penelitian berjalan dengan maksimal. Sebagai anak sudah mengetahui cara berkebun dan beberapa anak antuasias dan senang menanam tanaman melalui kegiatan berkebun ini.

Pada masa tahap pra tindakan tersebut dimaksudkan bahwa di tahap ini kita bisa melihat ketercapaian anak yang sudah bisa terlihat tetapi belum semuanya. Ada yang belum memasuki fase pencapaian beberapa siklus yang dilakukan, baru melihat di aspek penilaian awal anak saja. Setelah fase ini sudah terlihat, baru memasuki tahap siklus I. Pada siklus I ada beberapa anak saja yang kurang antuasi menanam tanaman dengan kegiatan berkebun. Anak hanya sebagai yang melakukan kegiatan berkebun dan mengganggu temannya yang sedang melakukan kegiatan berkebun di halaman sekolah. Dan ada anak yang sibuk dengan kegiatannya sendiri. Oleh karena itu, setelah penelitian siklus I selesai dilakukan peneliti melakukan refleksi terhadap hasil yang telah diperoleh. Refleksi ini berfungsi untuk melihat hasil dan pelaksanaan pada siklus pertama dengan lebih menentukan strategi dalam melakukan kegiatan berkebun.
Refleksi yang akan dilakukan adalah melakukan kegiatan menyiapkan dan memperkenalkan jenis tanaman untuk berkebun. Pada siklus ini telah terjadi penignkatan dibandingkan dengan kondisi pra tindakan. Kondisi pra tindakan karakter peduli lingkungan anak yang tuntas $0 \%$ (tidak ada anak), yang tidak tuntas 100\% (17 anak). Pada siklus I karakter peduli lingkungan anak yang tuntas 17\% (3 anak), dan yang tidak tuntas $83 \%$ (14 anak). Dari hasil penelitian dapat dilihat siklus I belum memenuhi indikator keberhasilan yaitu $75 \%$, maka dari peneliti harus melakukan penelitian selanjutnya ke siklus II. Permasalahan ini biasanya disebabkan oleh anak ketika berada di area berkebun itu anak merasa jijik, takut serta menangis ketika melihat hal-hal yang dianggap anak itu aneh apalagi anak kota biasanya jarang sekali bermain langsung ke daerah kebun atau daerah yang sering ditanami tanaman.

Selanjutnya, kita melakukan ke siklus II. Bahwa pada siklus II ini memperbaiki pembelajaran pada siklus I untuk melihat peningkatan karakter peduli lingkungan yang terjadi pada anak didik, jika di siklus I belum mengalami peningkatan. Ketika di siklus II sudah dapat dilihat perkembangan serta peningkatan karakter 
peduli lingkungan anak didik kelompok B.

Pada tindakan siklus II, kegiatan berkebun masih seperti siklus I hanya yang membedakan kalau di siklus I menanam sayur bayam di polibek, sedangkan di siklus II menanam sayur katu langsung ke kebun, selanjutnya peneliti memberikan perlengkapan untuk berkebun, lalu peneliti mencontohkan kepada anak didik cara menanam dengan baik. Kegiatan yang dilakukan pada siklus II ini tidak jauh berbeda dengan siklus I, namun pada siklus II cara menanamnya saja dan jenis tanaman juga yang berbeda. Pada siklus II karakter peduli lingkungan anak yang tuntas 77\% (13 anak), dan yang tidak tuntas $24 \%$ (4 anak). Karakter peduli lingkungan melalui kegiatan berkebun telah mengalami peningkatan sesuai dengan indikator keberhasilan.

Berdasarkan penelitian siklus I dapat dijelaskan keberhasilan peningkatan karakter peduli lingkungan anak melalui kegiatan berkebun ditinjau dari indikator pembelajaran, pembelajaran pada siklus I sudah berjalan dengan baik dan berhasil dari setiap aspek dan setiap kali pertemuannya, untuk kondisi awal (pra tindakan) memiliki kriteria tuntas $0 \%$ (tidak ada anak) dan tidak tuntas 100\% (17 anak). Ketika dilakukan untuk siklus I, Pertemuan 1. hasil tindakan sama seperti kondisi awal, belum ada peningkatan sama sekali. Pertemuan 2 sudah ada peningkatan sedikit mempunyai kriteria tuntas 6\% (1 anak) dan tidak tuntas 94\% (16 anak). Pertemuan 3, menaik sedikit kembali kriteria tuntas $11 \%$ (2 anak) dan tidak tuntas 89\% (15 anak). Pertemuan ke 4 meningkat kembali kriteria tuntas 17\% (3 anak) dan kriteria tidak tuntas $83 \%$ (14 anak). setelah semua di perhitungkan jumlah nilai akhir dan presentasenya bahwa penelitian yang dilakukan di siklus I belum mendekat kriteria keberhasilan 70\%, maka perlu diadakan siklus II.

Pada siklus II, dapat dijelaskan kriteria tuntas dan tidak tuntas dari masing-masing pertemuan dari siklus tersebut. Pertemuan 1, setelah dilakukan siklus I bahwa di siklus II memiliki persentase tuntas $23 \%$ (4 anak), dan tidak tuntas $77 \%$ (13 anak). Pertemuan 2, setelah dilakukan siklus I bahwa di siklus II memperoleh persentase tuntas 35\% (6 anak). Pertemuan 3, setelah dilakukan siklus I bahwa di siklus II memperoleh persentase tuntas $41 \%$ (7 anak) dan tidak tuntas 59\% (10 anak). Pertemuan 4, setelah dilakukan siklus I bahwa di siklus II memperoleh persentase tuntas 77\% (13 anak) dan tidak tuntas 23\% (4 anak).

Berdasarkan hasil dari penelitian yang dilakukan dari siklus I sampai ke 2, 
pertemuan 1 sampai 4 selalu adanya peningkatan walaupun jumlah persentase anak yang memiliki kriteria tuntas tidak terlau banyak. Tetapi diperjelas kembali, pada awal pra tindakan memiliki ketuntasan $0 \%$, dilakukan kembali ke siklus I memperoleh ketuntasan 17\% (3 anak), dan dilanjutkan kembali ke siklus II memperoleh ketuntasan 77\% (13 anak). Hasil penelitian dari karakter peduli lingkungan ini sudah memenuhi kriteria indikator keberhasilan 70\%. Anak sudah dapat memperlihatkan karakter peduli lingkungan melalui kegiatan berkebun.

\section{B. Pembahasan}

Penelitian yang telah dilakukan adalah jenis Penelitian Tindakan Kelas (PTK). Penelitian ini terdiri dari dua siklus, siklus I dan siklus II masing-masing terdiri dari perencanaan, tindakan dan observasi, serta refleksi. Sebelum memasuki siklus I dan II, ada tahap pra tindakan. Dimana masa pra tindakan ini sudah dapat melihat tingkat kecapaian anak, tetapi masa ini dilakukan satu kali saja pada saat observasi. Setelah itu kita masuk ke siklus I. Siklus I adalah suatu penelitian yang dilihat dari tahap awal sebelum memasuki siklus II. Siklus II adalah perubahan dari siklus I secara keseluruhan karakter peduli lingkungan anak mengalami peningkatan. Pada pelaksanaan siklus I penelitian berjalan dengan maksimal. Sebagai anak sudah mengetahui cara berkebun dan beberapa anak antuasias dan senang menanam tanaman melalui kegiatan berkebun ini.

Pada masa tahap pra tindakan tersebut dimaksudkan bahwa di tahap ini kita bisa melihat ketercapaian anak yang sudah bisa terlihat tetapi belum semuanya. Ada yang belum memasuki fase pencapaian beberapa siklus yang dilakukan, baru melihat di aspek penilaian awal anak saja. Setelah fase ini sudah terlihat, baru memasuki tahap siklus I. Pada siklus I ada beberapa anak saja yang kurang antuasi menanam tanaman dengan kegiatan berkebun. Anak hanya sebagai yang melakukan kegiatan berkebun dan mengganggu temannya yang sedang melakukan kegiatan berkebun di halaman sekolah. Dan ada anak yang sibuk dengan kegiatannya sendiri. Oleh karena itu, setelah penelitian siklus I selesai dilakukan peneliti melakukan refleksi terhadap hasil yang telah diperoleh. Refleksi ini berfungsi untuk melihat hasil dan pelaksanaan pada siklus pertama dengan lebih menentukan strategi dalam melakukan kegiatan berkebun.

Refleksi yang akan dilakukan adalah melakukan kegiatan menyiapkan dan memperkenalkan jenis tanaman untuk berkebun. Pada siklus ini telah terjadi 
penignkatan dibandingkan dengan kondisi pra tindakan. Kondisi pra tindakan karakter peduli lingkungan anak yang tuntas $0 \%$ (tidak ada anak), yang tidak tuntas 100\% (17 anak). Pada siklus I karakter peduli lingkungan anak yang tuntas $17 \%$ (3 anak), dan yang tidak tuntas 83\% (14 anak). Dari hasil penelitian dapat dilihat siklus I belum memenuhi indikator keberhasilan yaitu $75 \%$, maka dari peneliti harus melakukan penelitian selanjutnya ke siklus II. Permasalahan ini biasanya disebabkan oleh anak ketika berada di area berkebun itu anak merasa jijik, takut serta menangis ketika melihat hal-hal yang dianggap anak itu aneh apalagi anak kota biasanya jarang sekali bermain langsung ke daerah kebun atau daerah yang sering ditanami tanaman. Selanjutnya, kita melakukan ke siklus II. Bahwa pada siklus II ini memperbaiki pembelajaran pada siklus I untuk melihat peningkatan karakter peduli lingkungan yang terjadi pada anak didik, jika di siklus I belum mengalami peningkatan. Ketika di siklus II sudah dapat dilihat perkembangan serta peningkatan karakter peduli lingkungan anak didik kelompok B.

Pada tindakan siklus II, kegiatan berkebun masih seperti siklus I hanya yang membedakan kalau di siklus I menanam sayur bayam di polibek, sedangkan di siklus II menanam sayur katu langsung ke kebun, selanjutnya peneliti memberikan perlengkapan untuk berkebun, lalu peneliti mencontohkan kepada anak didik cara menanam dengan baik. Kegiatan yang dilakukan pada siklus II ini tidak jauh berbeda dengan siklus I, namun pada siklus II cara menanamnya saja dan jenis tanaman juga yang berbeda. Pada siklus II karakter peduli lingkungan anak yang tuntas $77 \%$ (13 anak), dan yang tidak tuntas $24 \%$ (4 anak). Karakter peduli lingkungan melalui kegiatan berkebun telah mengalami peningkatan sesuai dengan indikator keberhasilan.

Berdasarkan penelitian siklus I dapat dijelaskan keberhasilan peningkatan karakter peduli lingkungan anak melalui kegiatan berkebun ditinjau dari indikator pembelajaran, pembelajaran pada siklus I sudah berjalan dengan baik dan berhasil dari setiap aspek dan setiap kali pertemuannya, untuk kondisi awal (pra tindakan) memiliki kriteria tuntas $0 \%$ (tidak ada anak) dan tidak tuntas 100\% (17 anak). Ketika dilakukan untuk siklus I, Pertemuan 1. hasil tindakan sama seperti kondisi awal, belum ada peningkatan sama sekali. Pertemuan 2 sudah ada peningkatan sedikit mempunyai kriteria tuntas 6\% (1 anak) dan tidak tuntas 94\% (16 anak). Pertemuan 3, menaik sedikit kembali kriteria tuntas 11\% (2 anak) dan tidak tuntas $89 \%$ (15 anak). Pertemuan ke 4 
meningkat kembali kriteria tuntas $17 \%$ (3 anak) dan kriteria tidak tuntas 83\% (14 anak). setelah semua di perhitungkan jumlah nilai akhir dan presentasenya bahwa penelitian yang dilakukan di siklus I belum mendekat kriteria keberhasilan 70\%, maka perlu diadakan siklus II.

Pada siklus II, dapat dijelaskan kriteria tuntas dan tidak tuntas dari masing-masing pertemuan dari siklus tersebut. Pertemuan 1, setelah dilakukan siklus I bahwa di siklus II memiliki persentase tuntas $23 \%$ (4 anak), dan tidak tuntas $77 \%$ (13 anak). Pertemuan 2, setelah dilakukan siklus I bahwa di siklus II memperoleh persentase tuntas 35\% (6 anak). Pertemuan 3, setelah dilakukan siklus I bahwa di siklus II memperoleh persentase tuntas $41 \%$ (7 anak) dan tidak tuntas 59\% (10 anak). Pertemuan 4, setelah dilakukan siklus I bahwa di siklus

\begin{tabular}{|c|c|c|c|c|c|}
\hline $\begin{array}{l}\mathrm{N} \\
\mathrm{o}\end{array}$ & $\begin{array}{c}\text { Aspek } \\
\text { yang } \\
\text { dinilai }\end{array}$ & $\begin{array}{l}\text { Kond } \\
\text { isi } \\
\text { Awal }\end{array}$ & $\begin{array}{c}\text { Pertemu } \\
\text { an }\end{array}$ & $\begin{array}{l}\text { Sikl } \\
\text { us I }\end{array}$ & $\begin{array}{l}\text { Sikl } \\
\text { us II }\end{array}$ \\
\hline 1 & $\begin{array}{l}\text { Menunjukk } \\
\text { an } \\
\text { kepedulian }\end{array}$ & \multirow{4}{*}{$\begin{array}{l}\text { Tunta } \\
\text { s 0\% }\end{array}$} & Pert 1 & $0 \%$ & $\begin{array}{c}23 \% \\
4 \\
\text { anak } \\
\end{array}$ \\
\hline 2 & $\begin{array}{l}\text { Menunjukk } \\
\text { an sikap }\end{array}$ & & Pert 2 & $\begin{array}{c}6 \% \\
1 \\
\text { anak } \\
\end{array}$ & $\begin{array}{c}35 \% \\
6 \\
\text { anak } \\
\end{array}$ \\
\hline \multirow{2}{*}{3} & \multirow{2}{*}{$\begin{array}{l}\text { Menunjukk } \\
\text { an tindakan } \\
\text { (perbuatan) }\end{array}$} & & Pert 3 & $\begin{array}{c}11 \% \\
2 \\
\text { anak }\end{array}$ & $\begin{array}{c}41 \% \\
7 \\
\text { anak }\end{array}$ \\
\hline & & & Pert 4 & $\begin{array}{c}17 \% \\
3 \\
\text { anak }\end{array}$ & $\begin{array}{c}77 \% \\
13 \\
\text { anak } \\
\end{array}$ \\
\hline
\end{tabular}

II memperoleh persentase tuntas $77 \%$ (13 anak) dan tidak tuntas 23\% (4 anak).

Berdasarkan hasil dari penelitian yang dilakukan dari siklus I sampai ke 2, pertemuan 1 sampai 4 selalu adanya peningkatan walaupun jumlah persentase anak yang memiliki kriteria tuntas tidak terlau banyak. Tetapi diperjelas kembali, pada awal pra tindakan memiliki ketuntasan $0 \%$, dilakukan kembali ke siklus I memperoleh ketuntasan 17\% (3 anak), dan dilanjutkan kembali ke siklus II memperoleh ketuntasan 77\% (13 anak). Hasil penelitian dari karakter peduli lingkungan ini sudah memenuhi kriteria indikator keberhasilan 70\%. Anak sudah dapat memperlihatkan karakter peduli lingkungan melalui kegiatan berkebun.

Tabel 4.12. Rekapitulasi Keseluruhan Karakter Peduli Lingkungan Pada Pra Tindakan, Siklus I dan Siklus II 
PERNIK Jurnal PAUD, VOL 2 NO.1 September 2019

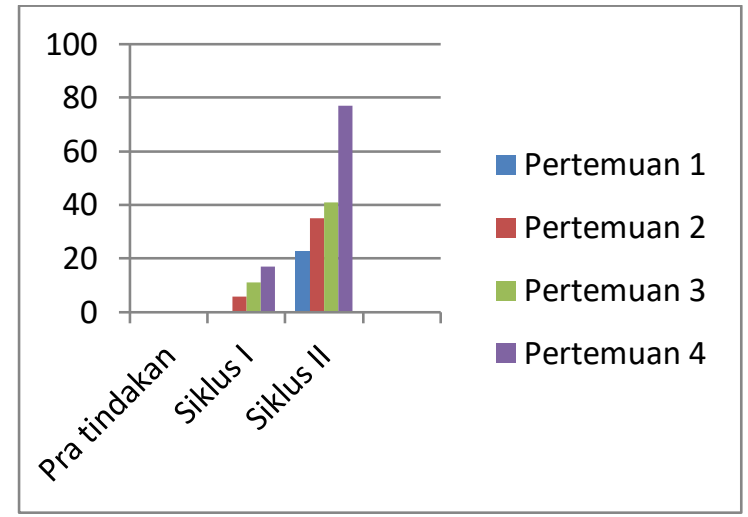

Diagram 4.12. Rekapitulasi Keseluruhan Karakter Peduli Lingkungan Pada Pra Tindakan, Siklus I dan Siklus II 


\section{KESIMPULAN DAN SARAN}

\section{A. Kesimpulan}

Dari hasil penelitian dan pembahasan yang telah peneliti jelaskan pada bab sebelumnya kesimpulan secara umum dalam penelitian ini adalah : bahwa kegiatan berkebun dapat meningkatkan karakter peduli lingkungan anak kelompok B3 RA Perwanida 4 Jakabaring Palembang. Adapun hasil kesimpulan secara khusus dalam penelitian ini adalah dari ketiga aspek mencapai nilai rata-rata karakter peduli lingkungan anak mencapai $70 \%$ dengan kriteria sangat baik, ini terbukti dengan diadakan siklus I dan II dengan rincian sebagai berikut:

Dari kondisi awal, siklus I dan siklus II. Bahwa hasil penelitian yang telah di dapat dari siklus I pertemuan 1-4, dan siklus II pertemuan 1-4, jumlah persentase kriteria keberhasilannya semakin meningkat walaupun tidak banyak, kondisi awal, karakter peduli lingkungan masih terlihat $0 \%$, setelah dilakukan tindakan siklus I, meningkat $17 \%$, berlangsung dari pertemuan 1 sampai 4, dan dilakukan siklus II, berlangsung dari pertemuan 1 sampai 4 meningkat menjadi 77\%. Siklus I dengan melakukan kegiatan berkebun dengan menanam sayur bayam di polibek dan siklus I menanam sayur katu langsung ke tanah. Maka penelitian ini cukup dilakukan dua siklus saja, karena kriteria keberhasilan anak didik dalam meningkatkan karakter peduli lingkungan melalui kegiatan berkebun sudah mencapai target yang ditentukan.

\section{B. Saran}

Berdasarkan pelaksanaan Penelitian Tindakan Kelas untuk meningkatkan karakter peduli lingkungan, terdapat beberapa saran yang perlu disimpulkan, yaitu:

\section{1) Anak didik}

Memberi pembelajaran dan motivasi agar anak lebih menanamkan sikap peduli dengan ciptaan allah baik itu tanaman sekitar sekolahnya, dan membantu dalam mengimbangi pertumbuhan otak dan saraf yang merupakan pusat terpenting dari apapun.

\section{2) Guru}

Dapat memberikan tindakantindakan dalam proses pembelajaran dan menanamkan hal yang memusatkan kepada sikap dan kepedulian anak terhadap lingkungannya.

\section{3) Peneliti}

Mengetahui pemecahan masalah tentang bagaimana cara meningkatkan karakter peduli lingkungan Anak Usia 
Dini melalui kegiatan berkebun pada anak usia PAUD.

\section{DAFTAR PUSTAKA}

Asmawati, luluk, dkk. (2014). Pengelolaan Kegiatan Pengembangan Anak Usia Dini. Jakarta: Universitas Terbuka.

Aqib, Zainal, dkk. (2017). PTK. Yogyakarta: Ar-Ruzz Media.

Kementerian Pendidikan Dan Kebudayaan. (2013). Pedoman Pendidikan Karakter Pendidikan Anak Usia Dini. Jakarta: Direktorat Pembinaan pendidikan anak usia dini dan direktorat jenderal pendidikan anak usia dini, nonformal dan informal

Mertler, Craig A. (2014). PENELITIAN TINDAKAN KELAS (Meningkatkan Sekolah Dan Memberdayakan Pendidik). Jakarta Barat: Hak Cipta Bahasa Indonesia.

Musfiroh, Tadkiroatun. Pengembangan (2010). Majemuk. Jakarta: Universitas Terbuka.

Nur, Hadi. (2014). Proceedings, Intregrating Knowledge with Science and Religius. Malaysia: Universitas Teknologi Malaysia.

Sanjaya, Wina. (2009). Penelitian Tindakan Kelas. Jakarta: PRENADAMEDIA GROUP (Divisi Kencana).

Setiyani, Nina. Pendidikan Karakter Peduli Lingkungan Melalui Program "Green Environment" di SMP Alam Ar Ridho Kota Semarang. Diss. Universitas Negeri Semarang, 2013.
Wardhani, Igak, dkk. (2013). Penelitian Tindakan Kelas. Jakarta: Universitas Terbuka.

Wahyudin, Uyu, dan Mubiar Agustin. 2011. Penilaian Perkembangan Anak Usia Dini. Bandung: PT. Refika Aditam 